\title{
Analisis Faktor Penerimaan Layanan e-Government dengan Menggunakan Model UTAUT2 dan GAM di Kabupaten Gunungkidul
}

\author{
Eko Setiawan ${ }^{1}$, Wing Wahyu Winarno ${ }^{2}$, Dhomas Hatta Fudholi1,"* \\ Fakultas Teknologi Industri, Teknik Informatika, Universitas Islam Indonesia, Yogyakarta, Indonesia \\ ${ }^{2}$ Prodi Akutansi, Sekolah Tinggi Ilmu Ekonomi YKPN, Yogyakarta, Indonesia

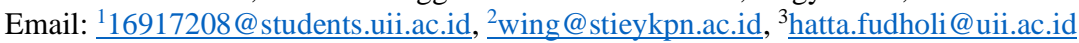 \\ Email Penulis Korespondensi: hatta.fudholi@uii.ac.id
}

\begin{abstract}
Abstrak-Pemerintah melalui Peraturan Presiden No. 95 Tahun 2018 tentang SPBE mendukung dan mewujudkan tata kelola pemerintah yang bersih, efektif dan transparan sehingga memiliki pelayanan public yang berkualitas dan terpercaya. Untuk meningkatkan masyarakat menggunakan layanan pemerintahan berbasis elektronik (e-government) diperlukan faktor apa saja yang mempengaruhi seseorang untuk menggunakan layanan e-government. Penelitian ini menggunakan model penelitian UTAUT2 dan Government Adoption Model (GAM) untuk mengetahui faktor-faktor yang mempengaruhi seseorang menggunakan e-government di Gunungkidul. Penelitian ini menggunnakan metode pengukuran PLS SEM dan menemukan bahwa faktor yang mempengaruhi penerimaan e-government yakni harapan usaha (effort expectation), kondisi fasilitas (facilitating condition, dan computer self efficacy.
\end{abstract}

Kata Kunci: e-Government; UTAUT2; GAM; PLS SEM; UTAUT

\begin{abstract}
Government through Presidential Regulation No. 95 of 2018 concerning SPBE supports and realizes clean, effective and transparent government governance so that it has quality and trusted public services. To improve society using egovernment based services, it is necessary what factors influence a person to use e-government services. This study uses the UTAUT2 research model and the Government Adoption Model (GAM) to determine the factors that influence a person using e-government in Gunungkidul. This study used the PLS SEM measurement method and found that the factors that influence egovernment acceptance are effort expectation, facilitating conditions, and computer self-efficacy.
\end{abstract}

Keywords: e-Government; UTAUT2; GAM; PLS SEM; UTAUT

\section{PENDAHULUAN}

Pesatnya perkembangan era teknologi 4.0 ini memiliki dampak langsung hingga ke seluruh lini masyarakat. Salah satu dampak positif dari perkembangan teknologi tersebut adalah munculnya sistem digitalisasi di dalam pemerintahan yang biasa disebut Electronic Government (E-Government) [1]. Pemerintahan di seluruh dunia berlomba-lomba menggunakan e-government untuk melakukan transformasi layanan publik dengan meningkatkan layanan-layanan publik masa depan dapat menciptakan pemerintahan melalui perkembangan internet [2]. Penggunaan e-government juga dapat mendorong transformasi birokrasi tradisional yang dapat menekan standarisasi dan efisiensi dalam pembiayaan, e-government juga dapat digunakan untuk kolaborasi dari internal ke eksternal dan juga bisa digunakan untuk layanan pelanggan.

Tinjauan Laporan Kinerja Nasional [3] telah menunjukkan bahwa dengan adanya e-government dapat memungkinkan warga negara mudah mendapatkan akses yang lebih luas dan lebih tepat waktu. Hadirnya egovernment menjadi salah satu revolusi terbaru yang mengubah cara berinteraksi antara bisnis dan masyarakat kepada pemerintahan. Layanan e-government berkaitan langsung dengan penggunaan teknologi informasi (WAN, internet, dan mobile computing) yang memiliki peranan dalam mengubah kondisi layanan pemerintah dengan warga, bisnis, dan pihak lain [4]. E-government memiliki kemampuan untuk mentransformasikan hubungan antara pemerintah dengan pemerintah (Government to Government $-\mathrm{G} 2 \mathrm{G}$ ), pemerintah dengan warganya (Government to Citizen - G2C), dan antara pemerintah dengan pelaku usaha (Government to Business - G2B) [5], [6]. Salah satu kelebihan dari layanan e-government adalah dapat meningkatkan partisipatif dan keterbukaan antara pemerintah dengan warga masyarakat atau pelaku usaha.

Perkembangan e-government di Indonesia semakin hari semakin pesat [7], dengan adanya Inpres No. 3 Tahun 2003 tentang strategi kebijakan nasional untuk perkembangan e-government yang berisikan tantang pengukuran berdasarkan tugas, fungsi, dan wewenang dari masing-masing untuk pengembangan e-government secara nasional dengan panduan Kebijakan Nasional dan Pengembangan Strategi e-government. Untuk mendukung dan mewujudkan tata kelola pemerintahan yang bersih, efektif, transparan, dan akutabel serta memiliki pelayanan public yang berkualitas dan terpercaya pemerintah mengeluarkan Peraturan Presiden (Perpres) Nomor 95 Tahun 2018 tentang Sistem Pemerintahan Berbasis Elektronik (SPBE). Untuk melaksanakan ketentuan dalam Peraturan Presiden Nomor 95 Tahun 2018 tentang SPBE, Menteri Pendayagunaan Aparatur Negara dan Reformasi Birokrasi Republik Indonesia menetapkan Permenpan RB Nomor 5 Tahun 2020 tentang pedoman manajeman resiko system pemerintah berbasis elektronik, dengan menyelenggarakan pemerintahan yang memanfaatkan teknologi informasi dan komunikasi guna memberikan layanan kepada pengguna SPBE [8].

Indonesia merupakan salah satu negara yang memiliki populasi yang tinggi dan termasuk dalam 5 besar pengunaan internet terbanyak di dunia [9]. Tingginya kesadaran terhadap akses internet tentunya dapat mempermudah dalam melakukan implementasi e-government di Indonesia, meskipun begitu program e- 
government di negara Indonesia juga harus dirancang dengan semudah mungkin sehingga dari berbagai kalangan dapat berpartisipasi dalam menggunakan e-government di Indonesia [10].

Pengembangan e-government di Indonesia saat ini masih berkutat dalam pengembangan sistem egovernment, namun pihak pemerintahan banyak yang belum melakukan evaluasi/pengukuran tentang kesuksesan dan penerimaan layanan e-government oleh penggunanya [11]. E-government dikatakan berhasil jika sudah memberikan manfaat yang yang optimal, layanan e-government di Indonesia harus bisa mencapai kondisi mature (kondisi matang atau sempurna). Untuk mencapai kondisi tersebut harus melalui sebuah proses, yang mana terdapat berbagai macam tahapan didalamnya [12]. Memiliki layanan e-government yang bagus tentunya dapat meningkatkan kualitas pelayanan pemerintah kepada masyarakat serta membuat proses semakin transparansi dan akuntabilitas sehingga masyarakat bisa melihat dan memantau perkembandan dan informasi pemerintahan secara lengkap [13].

Salah satu faktor penggunaan e-government juga dipengaruhi oleh kepercayaan penggunanya terhadap sistem yang disediakan oleh pemerintah [14], sehingga perlu dilakukan evaluasi terhadap penerimaan layanan egovernment di Indonesia. Penggunaan teknologi informasi itu untuk sebuah layanan pemerintahan yang nantinya akan dimanfaatkan oleh individu, kelompok ataupun orgasinasi merupakan inti dalam riset sistem informasi sebab sebelum digunakan harus dipastikan terlebih dahulu tentang penerimaan atau penolakan [15].

Mendorong penggunaan layanan e-government pemerintah memiliki strategi dan cara yang berbeda-beda, seperti halnya Pemerintah Kabupaten Gunungkidul yang menyelenggarakan kegiatan forum e-government. Acara yang diselenggarakan oleh Pemerintah Kabupaten Gunungkidul melalui Dinas Komunikasi dan Informatika menyelenggarakan forum rutin dengan tema "Optimalisasi Website sebagai sarana komunikasi dan sosialisasi kebijakan pembangunan" [16].

Masyarakat Gunungkidul juga telah memasuki fase masyarakat digital dengan ditandai tersedianya jaringan internet di seluruh wilayah se-Kabupaten Gunungkidul dan telah tersedianya Sistem Informasi Desa dalam platform website di tiap desa/kelurahan se-Kabupaten Gunungkidul [17].

Mewujudkan visi misi Kabupaten Gunungkidul yang berdaya saing, maju, mandiri dan sejahtera pada tahun 2025 tentunya dibutuhkan sebuah evaluasi untuk mengetahui penerimaan layanan e-government di kabupaten tersebut. Tujuan dari penelitian ini adalah untuk mencari faktor-faktor yang mempengaruhi adopsi layanan egovernment di Kabupaten Gunungkidul.

Penelitian ini memiliki tujuan untuk mengetahui factor-faktor apa saja yang mendominasi dalam penerimaan layanan e-government di Kabupaten Gunungkidul dengan menggunakan model UTAUT2 dan Government Adoption Model (GAM).

\section{METODOLOGI PENELITIAN}

\subsection{Model Penelitian}

Penelitian adopsi layanan e-government di pemerintahan sebelumnya sudah pernah dilakukan, salah satunya adalah penelitian yang dilakukan oleh Purwanto dan Susanto (2018) [18] pada pengaruh dimensi kepercayaan terhadap adopsi layanan e-government dengan menggunakan model SEM-PLS dengan menggunakan analisis deskriptif dan menghasilkan bahwa kepercayaan kepercayaan terhadap kualitas dan sistem informasi terhadap adopsi layanan e-government.

Penelitian yang dilakukan Muflihah dan Susanto (2017) [19], melakukan penelitian dengan cara mengumpulkan beberapa jurnal tentang adopsi layanan e-government dan hasilnya adalah faktor yang memperngaruhi layanan e-government adalah kenyamanan, kemudahan dalam pengunaan serta faktor kesiapan dari pemerintah.

Penelitian mengenai adopsi layanan Sistem Manajemen Daerah (SIMDA) Keuangan di Kabupaten Bondowoso yang dilakukan oleh Tobing (2019) [20] menggunakan metode penelitian self-report data yang berupa tulisan yang diberikan subyek penelitian dan juga berupa tangapan berupa kusioner. Peneliti tersebut mennunjukan hasil bahwa pengetahuan menjadi salah satu faktor yang mempengaruhi adopsi pengunaan layanan e-government.

Adopsi e-government menurut Alzahrani (2017) [21] bergantung dari kepercayaan dari warga negara, peneliti tersebut melakukan tinjauan literatur dengan mengumpulkan jurnal dan melakukan identifikasi terhadap faktor-faktor kepercayaan dalam e-government.

Penelitian lain dilakukan oleh Witarsyah (2017) [14] menyampaikan bahwa adopsi e-government dengan menggunakan model UTAUT dengan 4 kontruksi yakni performance expectancy, effort expectancy, social influence, facilitating conditions, serta menambahkan information quality, dan system quality dari metode DeLone and McLean, dan menambahkan kontruksi kepercayaan.

Salisa dkk (2019) [22] melakukan penelitian tentang analisis faktor penerimaan penggunaan sistem keuangan desa di Pemerintahan Desa Kabupaten Kudus dengan menggunakan pendekatan TAM dan TPB. Penelitian yang dilakukan oleh Salisa dkk (2019) [22] melakukan penelitian kualitatif dengan responden adalah pegawai pemerintahan desa di Kabupaten Kudus.

Rakhman (2020) [23] melakukan analisis studi penerimaan masyarakat Provinsi Sumatera Selatan terhadap layanan e-government dengan menggunakan model UTAUT. Penelitian yang dilakukan oleh Rakhman (2020) menunjukkan bahwa Social Influence (SI) memiliki pengaruh terhadap penggunaan layanan e-govenrnment di Sumatera Selatan. 


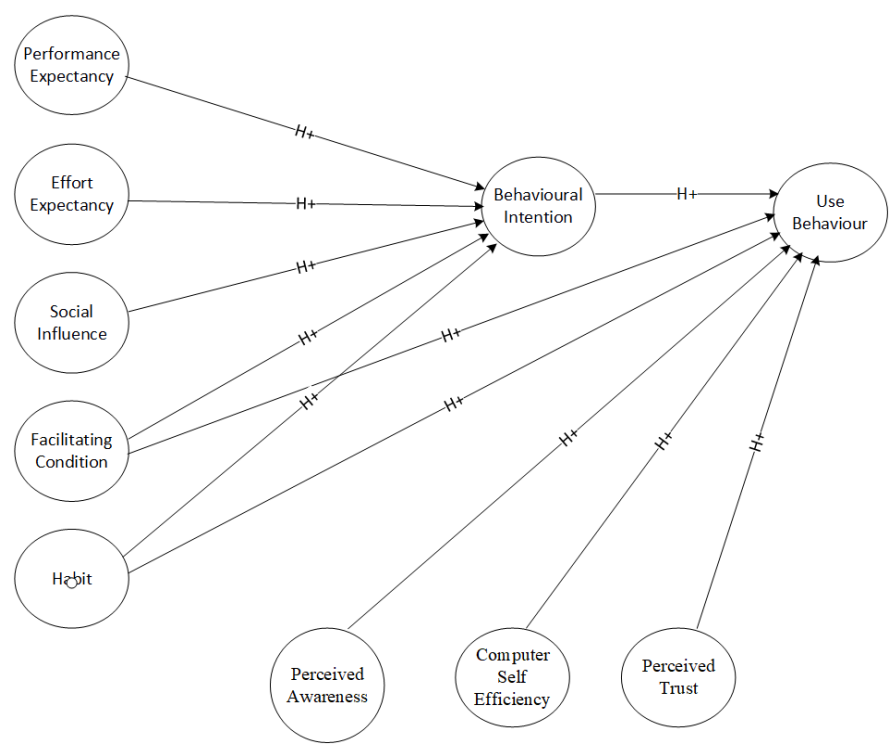

Gambar 1. Model Penelitian

Peneliti menggunakan desain indikator kuesioner untuk UTAUT2 menggunakan indikator yang digunakan oleh Venkatesh, Thong (2012) [24] dan Government Adoption Model (GAM) yang digunakan oleh Shareef et al (2011) [25] yang disesuaikan dengan objek penelitian yakni pengguna layanan e-government di Kabupaten Gunungkidul.

\subsection{Penentuan Sampel dan Penggumpulan Data}

Pengambilan sampel data pada penelitian ini dilakukan di wilayah Kabupaten Gunungkidul. Penelitian ini menggunakan metode positivistik dengan data kuantitatif. Peneliti mengumpulkan data dengan menggunakan kuisioner untuk mendapatkan data yang kemudian dilakukan analisis data. Pengumpulan data dilakukan dengan cara menyebarkan kuisioner secara online di forum dan sosial media dengan target masyarakat di Kabupaten Gunungkidul. Peneliti menggunakan metode pengukuran dan analisis PLS SEM dengan jumlah sampel data yang dibutuhkan 10 kali jumlah indikator terbanyak yang membentuk sebuah variabel [26], sehingga dalam penelitian ini peneliti akan mengunakan sampel data minimal sejumlah 40 terhitung dari jumlah indikator terbanyak adalah 4. Untuk memberikan tanggapan dari para pengguna dalam kuisioner, setiap partisikan akan mengisikan dengan memilih skala Likert mulai dari 1 (sangat tidak setuju) hingga 5 (sangat setuju).

\subsection{Hipotesis}

Berdasarkan hasil dari studi pustaka dalam penelitian ini akan dibangun dengan beberapa hipotesis sesuai dengan model yang dibangun. Hipotesis kemudian akan diujikan dan dilakukan analisis dengan menggunakan metode PLS SEM.

H1: Performance Expectancy (PE) akan berpengaruhi positif terhadap Behavioural Intention (BI)

Venkatesh, Thong (2012) [24] mendefinisikan ulang dan mengadaptasi model utaut asli kedalam konteks konsumen. Harapan kinerja (performance expectation) adalah tingkat seseorang atau individu percaya bahwa menggunakan teknologi akan memberikan manfaat dalam melakukan aktivitas. Itu menunjukkan bahwa seorang akan menggunakan sebuah teknologi jika meraka yakin akan mendapatkan hasil positif setelah menggunakannya [27]. Harapan kinerja (Performance Expectancy) diharapkan akan menjadi salah satu faktor terpenting yang mempengaruhi niat penerimaan [28].

H2: Effort Expectancy (EE) akan berpengaruh positif terhadap Behavioural Intention (BI)

Harapan usaha merupakan tingkat kemudahan dalam menggunakan teknologi bagi para pengunanya [29]. Selain itu dalam penelitian yang dilakukan oleh Al-Shafi \& Weerakkody(2009) [30] dan Gupta et al. (2008) [31] yang dilakukan di India, dan Qatar secara menunjukkan bahwa harapan usaha mempengaruhi niat penggunaan sebuah teknologi. Layanan e-government juga akan mudah digunakan oleh seluruh masyarakat, sehingga hal ini menunjukkan bahwa harapan usaha memiliki kemungkinan akan kuat mempengaruhi niat penggunaan.

H3: Social Influence (SI) akan berpengaruh positif terhadap Behavioural Intention (BI)

Pengaruh sosial (social influence) merupakan sejauh mana seseorang merasakan bahwa penggunaan teknologi tersebut akan dipengaruhi oleh orang sekitar seperti keluarga dan teman [29]. Penelitian sebelumnya yang dilakukan oleh Al-Shafi dan Weerakkody (2009) [30], serta Yi-Shun Wang (2009) [32] menunjukkan bahwa pengaruh sosial mempengaruhi niat penggunaan sebuah teknologi. Hal tersebut menunjukkan bahwa seseorang menggunakan layanan e-government karena ada pengaruh orang lain, sehingga pengaruh sosial dimungkinkan akan mempengaruhi seseorang untuk berniat menggunakan layanan e-government. 
H4a: Facilitating Condition (FC) akan berpengaruh positif terhadap Behavioural Intention (BI)

H4b: Facilitating Condition (FC) akan berpengaruh positif terhadap Use Behaviour (UB)

Kondisi fasilitas (Facilitating Condition) juga menunjukkan bahwa seseorang percaya adanya infrastruktur ataupun fasilitas yang dapat mempermudah mereka untuk menggunakan sebuah teknologi informasi [29]. Infrastruktur jaringan juga menjadi salah satu hal yang dibutuhkan untuk pengguna nyaman dalam menggunakan, selain itu juga fasilitas lain seperti tutorial penggunaan layanan e-government bisa memberikan kemudahan dan dapat memberikan bantuan untuk pengguna. Sehingga kondisi fasilitas dimungkinkan memiliki keterikatan mempengaruhi niat dan prilaku masyarakat dalam menggunakan layanan e-government.

H5a: Habit (HB) akan berpengaruh positif terhadap Behavioural Intention (BI)

H5b: Habit (HB) akan berpengaruh positif terhadap Use Behaviour (UB)

Kebiasaan (habit) sebelumnya akan mempengaruhi dan menjadi penenti prilaku saat ini [33]. Sementara Venkatesh dan Thong (2012) [24] menyebutkan bahwa kebiasaan juga menjadi pengaruh seseorang tersebut menggunakan sebuah teknologi.

H6: Behavioural Intention (BI) akan berpengaruh positif terhadap Use Behaviour (UB)

Berdasarkan penelitian yang dilakukan oleh Venkatesh \& Morris (2003) [29] menunjukkan bahwa niat prilaku setiap individu memilihi pengaruh besar terhadap penggunaan sebuah teknologi. Sementara dalam teori psikologi [34], berpendapat bahwa setiap prilaku setiap pengguna itu dipengaruhi oleh niat perilaku.

H7: Perceived Awareness (PA) akan berpengaruh positif terhadap Use Behaviour (UB)

Kesadaran yang dirasakan untuk mempelajari karakteristik sebuah sistem dengan menyadari fungsi strategis [25]. Kesadaran akan manfaat yang dirasakan diangkap dapat mempengaruhi adopsi layanan e-government [25]. Sehingga kesadaran yang dirasakan kemungkinan besar akan memperkuat orang untuk menggunakan layanan e-government.

H8: Computer Self Efficiency (CSE) akan berpengaruh positif terhadap Use Behaviour (UB)

CSE merupakan sebuah penilaian kemampuan seseorang dalam menggunakan teknologi untuk keperluan tertentu [27]. Sebelumnya penelitian yang dilakukan oleh Chan dkk (2010) [35] tentang adopsi teknologi menemukan hubungan positif antara CSE dengan penggunaan teknologi. Sehingga CSE dimungkinkan akan memperkuat orang untuk menggunakan layanan e-government di Kabupaten Gunungkidul.

H9: Perceived Trust (PT) akan berpengaruh positif terhadap Use Behaviour (UB)

Kepercayaan memiliki peran penting dalam menerapkan layanan e-government [36]. Penelitian yang dilakukan oleh Carter dan Belanger (2005) [37] menyebutkan bahwa warga negara yang mempercayai pemerintah akan lebih cenderung menggunakan layanan e-government jika teknologi yang digunakan memperikan perlindungan yang memadai terhadap resiko. Sehingga kepercayaan akan memiliki kemungkinan besar memperkuat masyarakat dalam menggunakan layanan e-government.

\section{HASIL DAN PEMBAHASAN}

\subsection{Gambaran Umum Responden}

Penelitian ini dilakukan di Kabupaten Gunungkidul. Penelitian ini dilakukan dengan cara melakukan survey online yang dilakukan selama bulan September - Oktober 2020. Jumlah responden yang mengikuti survey sebanyak 88 peserta sementara data yang dapat digunakan dan valid terdapat 73 data, sementara data lainnya yang tidak digunakan karena tepengisian kuisioner dari peserta tidak lengkap dan juga terdapat beberapa duplikasi data.

Penelitian ini menggunakan metode pengukuran PLS SEM dengan menggunakan software SmartPLS. Jumlah responden sudah mencukupi minimal dengan metode PLS.

Tabel 1. Data Demografi

Data Demografi Jumlah \%

\begin{tabular}{clrr}
\hline \multirow{2}{*}{ Jenis kelamin } & Perempuan & 35 & 44,4 \\
\cline { 2 - 4 } & Laki-laki & 44 & 55,6 \\
\hline \multirow{2}{*}{ Pedidikan Terakhir } & SMA & 33 & 41,8 \\
\cline { 2 - 4 } & D3 & 5 & 6,3 \\
\cline { 2 - 4 } & S1 & 41 & 51,9 \\
\hline \multirow{2}{*}{ Umur } & $<20$ tahun & 1 & 1,3 \\
\cline { 2 - 4 } & $20-30$ tahun & 41 & 51,9 \\
\cline { 2 - 4 } & $30-40$ tahun & 6 & 39,2 \\
\cline { 2 - 4 } & $>40$ tahun & & 7,6 \\
\hline Sosial media & Facebook & 79 & 100 \\
\hline
\end{tabular}




\subsection{Analisis Data}

\begin{tabular}{lrr} 
Instagram & 56 & 70,89 \\
\hline Whatsapp & 67 & 84,81 \\
\hline Line & 18 & 22,78 \\
\hline Pinterest & 7 & 8,86 \\
\hline Tik Tok & 6 & 7,59 \\
\hline Linkedin & 3 & 3,80 \\
\hline Twitter & 19 & 24,05
\end{tabular}

Data penelitian yang telah didapatkan kemudian akan dilakukan analisis untuk membuktikan hipotesis. Peneliti melakukan analisis data dengan menggunakan metode PLS SEM dengan menggunakan software SmartPLS. Sementara untuk metode PLS sendiri akan dilakukan dua tahap yakni model pengukuran (evaluasi outer model) dan model structural (evaluasi inner model).

\subsubsection{Evaluasi Outer Model (Model Pengukuran)}

Pada tahap model pengukuran ini dilakukan uji validitas dan reabilitas. Uji validitas akan mengukur setiap indikator yang menyusul suatu variabel, sementara pada tahapan uji reabilitas akan menguji variabel yang menyusul model.

Pada tahapan uji validitas akan mengukur nilai factor loading (FL) dan cross loading setiap indikator. Hair ( 2011) dan Haryono (2017) menyebutkan bahwa nilai factor loading dari setiap indikator yang akan diggunakan untuk analisis FL $\geq 0.5$ sementara nilai cross loading setiap indikator harus lebih besar dari nilai cross loading pada variabel atau konstruk lainnya. Pada pengukuran factor loading awal indikator BI3, dan EE4 memiliki nilai dibawah 0,5, sehingga mengakibatkan indikator BI3 dan EE4 harus dihapus untuk membuat model valid. Selanjutnya dilakukan pengukuran ulang untuk factor loading hasilnya seperti tabel di bawah dan tidak ada indikator yang factor loading dibawah 0,5 nilainya. Pengujian validitas outer model selanjutnya adalah melihat cross loading dari indikator terhadap seluruh variabel atau konstruk yang ada. Nilai loading indikator terhadap variabelnya harus lebih besar dari nilai loading indikator terhadap variabel lainnya [38]. Pada pengujian cross loading semua indikator memenuhi kriteria.

Tabel 2. Factor loading

\begin{tabular}{ll}
\hline Indikator & $\begin{array}{l}\text { Factor } \\
\text { Loading }\end{array}$ \\
\hline BI1 & 0.937 \\
\hline BI2 & 0.850 \\
\hline CSE1 & 0.939 \\
\hline CSE2 & 0.899 \\
\hline CSE3 & 0.854 \\
\hline EE1 & 0.901 \\
\hline EE2 & 0.917 \\
\hline EE3 & 0.789 \\
\hline FC1 & 0.897 \\
\hline
\end{tabular}

\begin{tabular}{ll}
\hline Indikator & $\begin{array}{l}\text { Factor } \\
\text { Loading }\end{array}$ \\
\hline FC2 & 0.931 \\
\hline FC3 & 0.895 \\
\hline FC4 & 0.825 \\
\hline HB1 & 0.872 \\
\hline HB2 & 0.895 \\
\hline HB3 & 0.822 \\
\hline PA1 & 0.822 \\
\hline PA2 & 0.844 \\
\hline PA3 & 0.627
\end{tabular}

\begin{tabular}{ll}
\hline Indikator & $\begin{array}{l}\text { Factor } \\
\text { Loading }\end{array}$ \\
\hline PE1 & 0.816 \\
\hline PE2 & 0.928 \\
\hline PE3 & 0.820 \\
\hline PE4 & 0.753 \\
\hline PT1 & 0.820 \\
\hline PT2 & 0.916 \\
\hline PT3 & 0.759 \\
\hline SI1 & 0.943 \\
\hline SI2 & 0.945 \\
\hline UB & 1.000
\end{tabular}

Selanjutnya, pengukuran outer model selanjutnya adalah uji reabilitas. Pada pengujuan reabilitas memiliki beberapa kriteria yang harus dipenuhi yakni nilai Cronbach's Alfa $(\mathrm{CA})>0.6$ nilai Composite Reability $(\mathrm{CR})>$ 0,6 serta nilai Average Variance Extracted (AVE) > 0,5. Nilai CA dan CR dapat dilihat pada tabel 4 di bawah.

Tabel 3. Nilai CA,CR, Dan AVE

\begin{tabular}{llll}
\hline Variabel & $\begin{array}{c}\text { Cronbach's } \\
\text { Alfa }\end{array}$ & $\begin{array}{l}\text { Composite } \\
\text { Reliability }\end{array}$ & $\begin{array}{l}\text { Average } \\
\text { Variance } \\
\text { Extracted }\end{array}$ \\
\hline BI & 0.804 & 0.911 & 0.836 \\
CSE & 0.880 & 0.926 & 0.806 \\
EE & 0.860 & 0.914 & 0.780 \\
FC & 0.910 & 0.937 & 0.789 \\
HB & 0.829 & 0.898 & 0.747 \\
PA & 0.668 & 0.840 & 0.727 \\
PE & 0.854 & 0.898 & 0.688 \\
PT & 0.782 & 0.872 & 0.696 \\
SI & 0.877 & 0.940 & 0.887 \\
UB & 1.000 & 1.000 & 1.000 \\
\hline
\end{tabular}


Berdasarkan hasil pengukuran tersebut menunjukkan bahwa semua variabel memenuhi uji reabilitas. Pengukuran outer model telah memenuhi uji validitas dan reabilitas hal ini menunjukkan bahwa pengukuran selanjutnya untuk Inner Model dapat dilakukan.

\subsubsection{Evaluasi Inner Model (Model Struktural)}

Pengukuran model struktural atau Inner model dilakukan bertujuan untuk melihat hubungan antara variabel dalam model serta untuk menguji hipotesis yang telah ditetapkan. Pada pengukuran model struktural ini akan melihat nilai Pvalue dengan nilai signifikansi Pvalue $<0,1$ (cukup signifikan), Pvalue $<0.05$ (signifikan) dan Pvalue $<$ 0,01 (sangat signifikan). Pengukuran menggunakan PLS akan menggunakan bootstrap resampling untuk mendapatkan nilai Pvalues dengan 500 iterasi untuk resampling dengan menggunakan software SmartPLS.

Pada pengukuran model struktural melihat hubungan variabel dengan melihat nilai path cofficients. Nilai positif dari path cofficient menunjukkan hubungan positif antar variabel sedangkan untuk nilai path cofficient negatif menunjukkan hubungan negatif antar variabel. Nilai Pvalue dan path cofficient dapat dilihat pada tabel 4 di bawah.

Tabel 4. Pvalues dan Path Cofficient

\begin{tabular}{lllll}
\hline Konstruk & Pvalues & $\begin{array}{l}\text { Path } \\
\text { Coefficients }\end{array}$ & Signifikan & Hasil Hipotesis \\
\hline H1: PE => BI & 0.976 & 0.003 & $* *$ & Ditolak \\
H2: EE => BI & 0.005 & 0.360 & & Diterima \\
H3: SI => BI & 0.344 & -0.102 & $* * *$ & Ditolak \\
H4a: FC => BI & 0.001 & 0.473 & & Diterima \\
H4b: FC => UB & 0.936 & -0.013 & & Ditolak \\
H5a: HB => BI & 0.689 & -0.050 & & Ditolak \\
H5b: HB => UB & 0.323 & 0.168 & & Ditolak \\
H6: BI => UB & 0.495 & -0.099 & $*$ & Ditolak \\
H7: PA => UB & 0.328 & 0.155 & & Diterima \\
H8: CSE => UB & 0.076 & 0.291 & Ditolak \\
H9: PT $=$ > UB & 0.376 & -0.144 & & \\
\hline
\end{tabular}

Keterangan : ***: sangat signifikan (Pvalues $<0,01)$

$$
\begin{aligned}
& * * \text { : signifikan }(\text { Pvalues }<0,05) \\
& * \text { : cukup signifikan }(\text { Pvalues }<0,1)
\end{aligned}
$$

Berdasarkan pengujian yang telah dilakukan nilai Pvalues dan path coefficient hasil dari penelitian ini dapat melihat signifikansi hasil dan hubungan antar variabel yang diujikan. Setelah dilakukan pengujian terdapat tiga hubungan antar variabel atau konstruk yang signifikan yakni $\mathrm{EE}=>\mathrm{BI}, \mathrm{FC}=>\mathrm{BI}$, dan CSE $=>\mathrm{UB}$.

Pengukuran terakhir adalah memvalidasi model dengan melihat nilai R2. Pengukuran pada penelitian ini dilakukan dua kali untuk melihat seberapa besar faktor yang mempengaruhi penerimaan layanan e-government. Pada penelitian ini, peneliti melakukan menguji model UTAUT2 dan model UTAUT2 yang ditambahkan variabel dari Model GAM. Berikut ini adalah hasil pengukuran R2:

\begin{tabular}{|c|c|c|}
\hline $\begin{array}{l}\text { Variabel } \\
\text { Dependent }\end{array}$ & $\begin{array}{l}\mathrm{R}^{2} \\
\text { (UTAUT2) }\end{array}$ & $\mathrm{R}^{2}(\mathrm{UTAUT} 2$ + GAM) \\
\hline BI & 0,507 & 0,507 \\
\hline UB & 0,128 & 0,178 \\
\hline
\end{tabular}

Tabel 5. Hasil pengukuran r2

Berdasarkan tabel 5, hasil pengukuran R2 pada UTAUT2 ditambahkan model GAM nilai pada variabel BI sebesar 0,507 dan variabel UB 0,178. Sehingga didapatkan bahwa variabel independen yang mempengaruhi BI sebesar 50,7\% sedangkan variabel independen yang mempengaruhi UB sebesar 17,8\%. Pada hasil pengukuran $\mathrm{R}^{2}$ pada model UTAUT2 ditambah dengan model GAM mengalami penambahan dibanding dengan model UTAUT2.

\section{a. UTAUT2}

Berdasarkan Tabel 4 tersebut menunjukkan pengaruh sebuah variabel independent terhadap yang dipengaruhi dengan melihat nilai negatif atau positif path cofficien. Variabel EE mempengaruhi BI dengan positif dan signifikan, variabel FC mempengaruhi BI dengan positif dan sangat signifikan, sementara variabel CSE mempengaruhi UB dengan positif dan cukup signifikan.

Hasil dari penelitian ini menyatakan bahwa harapan usaha (effort expectation) dan kondisi fasilitas (facilitating condition) telah terbukti menjadi salah satu faktor yang mempengaruhi seseorang menggunakan layanan e-government di Kabupaten Gunungkidul. Pada penelitian sebelumnya yang dilakukan oleh Thesa dan Nofiantoro (2016) juga menunjukkan hal serupa bahwa harapan usaha dan juga kondisi fasilitas mempengaruhi penerimaan seseorang menggunakan e-filling. 
Sementara performance expectancy, sosial influence, habit tidak terbukti signifikan mempengaruhi niat prilaku seseorang menggunakan layanan e-government di Kabupaten Gunungkidul. Hal ini bertolak belakang dengan penelitian yang dilakukan oleh Thesa dan Nofiantoro (2016) yang menunjukkan bahwa performance expectancy berpengaruh terhadap penggunaan layanan. Berbeda dengan penelitain yang dilakukan oleh Saragih \& Septamia (2019) yang menyebutkan bahwa sosial influence mempengaruhi seseorang menngunakan sebuah aplikasi, sementara pada penelitian ini sosial influence tidak mempengaruhi seseorang dalam menggunakan layanan e-government di Kabupaten Gunungkidul.

\section{b. Government Adoption Model}

Model GAM yang digunakan dalam penelitian ini memiliki satu hipotesis yang terbukti mempengaruhi seseorang untuk biasa menggunakan layanan e-government di Kabupaten Gunungkidul. Computer self efficiency terbukti secara positif mempengaruhi kebiasaan pengguna (use behavior) penelitian ini senada dengan penelitian Putra dkk (2018) bahwa computer selft efficiency berpengaruh dalam penerimaan e-government. Namun, penelitian ini berbanding terbaik dengan penelitian sebelumnya yang dilakukan oleh Dewi dan Mudjahidin (2014) dan Oktavia (2020) yang pada pada penelitian tersebut computer self efficiency tidak terbukti mempengaruhi seseorang untuk menggunakan layanan e-government.

Pada penelitian ini Perceived Awareness dan Perceived Trust tidak terbukti mempengaruhi niat seseorang untuk menggunakan layanan e-government.

\section{KESIMPULAN}

Tujuan dari penelitian ini adalah untuk mencari faktor yang mempengaruhi untuk menggunakan layanan egovernment di Kabupaten Gunungkidul. Hasil dari penelitian ini menunjukkan bahwa dari beberapa indikator yang ujikan terdapat 3 indikator yang secara signifikan mempengaruhi seseorang untuk menggunakan layanan egovernment.

Faktor-faktor yang mempengaruhi tersebut yakni harapan usaha (effort expectation), kondisi fasilitas (facilitating condition) terbukti signifikan mempengaruhi niat prilaku seseorang mennggunakan layanan egovernment. Sementara computer self efficacy terbukti signifikan mempengaruhi perilaku penggunaan (use behaviour).

\section{REFERENCES}

[1] E. S. Holle, "Pelayanan Publik Melalui Electronic Government: Upaya Meminimalisir Praktek Maladministrasi dalam Meningkatan Public Service Oleh : Erick S. Holle,” J. SaSi, vol. 17, no. 3, pp. 21-30, 2011.

[2] A. Tat-kei Ho, "Reinventing Local Governments and the E-Government Initiative A Paradigm Shift of Public Service," Public Adm. Rev., vol. 62, no. 4, pp. 434-444, 2002, doi: 10.1111/0033-3352.00197.

[3] A. Gore, "Reengineering Through Technology," https://govinfo.library.unt.edu/npr/library/reports/itexe.html, 1993. .

[4] Word Bank, "E-Government," 2012.

[5] M. O. Ahmad, J. Markkula, and M. Oivo, "Factors affecting e-government adoption in Pakistan: A citizen's perspective," Transform. Gov. People, Process Policy, vol. 7, no. 2, pp. 225-239, 2013, doi: 10.1108/17506161311325378.

[6] D. R. Mason-Jones, R. and Towill, "Factors affecting citizen adoption of transactional Factors affecting citizen adoption of transactional electronic government," Int J Logist. Manag., 1999.

[7] N. P. Yunita, "Kondisi Terkini Perkembangan e-Government di Indonesia : Praktik Pemerintah dan Persepsi Publik," 2018.

[8] Menpan, "Peraturan Menteri Pendayagunaan Aparatur Negara dan Reformasi Birokrasi Republik Indonesia Nomor 5 Tahun 2020 Tentang Pedoman Manajemen Resiko SIstem Pemerintah Berbasis Elektronik,” pp. 1-30, 2020.

[9] S. KEMP, "Digital trends 2019: Every single stat you need to know about the internet," Hootsuite, 2019.

[10] F. Wahid and M. K. Sein, "Steering institutionalization through institutional work: The case of an eProcurement system in indonesian local government," Proc. Annu. Hawaii Int. Conf. Syst. Sci., pp. 4264-4274, 2014, doi: 10.1109/HICSS.2014.527.

[11] Q. E. Muftikhali and T. D. Susanto, "Kumpulan Model Maturity E-Government: Sebuah Ulasan Sistematis," J. Teknol. Inf. dan Ilmu Komput., vol. 4, no. 4, p. 311, 2017, doi: 10.25126/jtiik.201744367.

[12] S. W. Sihwi, "Pengembangan Process Maturity Framework pada E-Government di Indonesia," Universitas Indonesia, 2009.

[13] N. D. Retnowati, D. Retnowati, S. Tinggi, and T. Adisutjipto, "Peranan E-Government Dalam Rangka Mewujudkan Good Governance Bagi Masyarakat," vol. 2008, no. semnasIF, pp. 205-211, 2008.

[14] D. Witarsyah, T. Sjafrizal, M. F. MD Fudzee, and M. A. Salamat, "The Critical Factors Affecting e-Government Adoption in Indonesia: A Conceptual Framework," Int. J. Adv. Sci. Eng. Inf. Technol., vol. 7, no. 1, p. 160, 2017, doi: 10.18517/ijaseit.7.1.1614

[15] S. Asturi, "Ketidakpastian Tugas Sebagai Variabel Moderating Terhadap Hubungan Kemanfaatan Teknologi Informasi Dan Kepuasan Pengguna Akhir," Thesis Progr. Pascasarjana, Univ. Gajah Mada, 2001.

[16] Kominfo, "Forum E-Government Desa Se-Kabupaten Gunungkidul," kominfo Gunungkidul, 2017.

[17] F. Wicaksono, "Dilema Implementasi E-Goverment: Analisis Partisipasi Masyarakat," vol. 2, no. 3, pp. 227-236, 2018

[18] A. Purwanto and T. D. Susanto, "Pengaruh Dimensi Kepercayaan Terhadap Adopsi Layanan E-Government," J. Inf., 
vol. 3, no. 1, pp. 12-18, 2018, doi: 10.25139/ojsinf.v3i1.520.

[19] Y. Muflihah and T. D. Susanto, "<Title/>," J. Teknol. Inf. dan Ilmu Komput., vol. 4, no. 4, p. 304, 2017, doi: 10.25126/jtiik.201744366.

[20] D. S. Tobing, E. S. Wahyudi, and H. Handriyono, "Pengaruh Kemampuan Teknik Personal, Pelatihan Operator Sistem Terhadap Kinerja Sistem Manajemen Daerah (Simda) Keuangan Melalui Adopsi Layanan Di Pemerintah Kabupaten Bondowoso," Bisma, vol. 12, no. 3, p. 377, 2019, doi: 10.19184/bisma.v12i3.9006.

[21] L. Alzahrani, W. Al-Karaghouli, and V. Weerakkody, "Analysing the critical factors influencing trust in e-government adoption from citizens' perspective: A systematic review and a conceptual framework," Int. Bus. Rev., vol. 26, no. 1, pp. 164-175, 2017, doi: 10.1016/j.ibusrev.2016.06.004.

[22] N. R. Salisa, I. N. Aeni, and A. A. Chamid, "Analisis Faktor-faktor Penerimaan Penggunaan Sistem Keuangan Desa: Pendekatan TAM dan TPB," Ekon. dan Bisnis, vol. 6, no. 1, p. 34, 2019, doi: 10.35590/jeb.v6i1.829.

[23] M. Rakhman, "Study Penerimaan Masyarakat Propinsi Selatan Terhadap Layanan E-Government Menggunakan Model Unified Theory of Acceptance And Use of Technology ( UTAUT )," J. Ilmu Komput. dan Sist. Inf., vol. 01, no. 01, pp. $1-14,2020$.

[24] X. X. Viswanath Venkatesh, James Y. L. Thong, "Consumer Acceptance And Use Of Information Technology: Extending The Unified Theory Of Acceptance And Use Of Technology," vol. 36, no. 1, pp. 157-178, 2012.

[25] M. A. Shareef, V. Kumar, U. Kumar, and Y. K. Dwivedi, "E-Government Adoption Model (GAM): Differing service maturity levels," Gov. Inf. Q., vol. 28, no. 1, pp. 17-35, 2011, doi: 10.1016/j.giq.2010.05.006.

[26] J. F. Hair, C. M. Ringle, and M. Sarstedt, "PLS-SEM: Indeed a silver bullet,” J. Mark. Theory Pract., vol. 19, no. 2, pp. 139-152, 2011, doi: 10.2753/MTP1069-6679190202.

[27] D. R. Compeau and C. A. Higgins, "Computer Self-Efficacy: Measure and Initial Development of a Test," MIS Q., vol. 19, no. 2, pp. 189-211, 1995, doi: 10.1520/E2368-10.

[28] Y. Luo, Q. Xue, and B. Han, "How emerging market governments promote outward FDI: Experience from China," $J$. World Bus., vol. 45, no. 1, pp. 68-79, 2010, doi: 10.1016/j.jwb.2009.04.003.

[29] G. B. D. Viswanath Venkatesh, Michael G. Morris, "Unusual formations of superoxo heptaoxomolybdates from peroxo molybdates," Inorg. Chem. Commun., vol. 67, no. 3, pp. 95-98, 2003, doi: 10.1016/j.inoche.2016.03.015.

[30] S. Al-Shafi and V. Weerakkody, "Understanding citizens' behavioural intention in the adoption of e-government services in the state of Qatar," 17th Eur. Conf. Inf. Syst. ECIS 2009, no. June 2014, 2009.

[31] B. Gupta, S. Dasgupta, and A. Gupta, "Adoption of ICT in a government organization in a developing country: An empirical study,” J. Strateg. Inf. Syst., vol. 17, no. 2, pp. 140-154, 2008, doi: 10.1016/j.jsis.2007.12.004.

[32] Y.-W. S. Yi-Shun Wang, "Why do people use information kiosks? A validation of the Unified Theory of Acceptance and Use of Technology," Gov. Inf. Q., 2009.

[33] M. Fishbein and I. Ajzen, "The Influence of Attitudes on Behavior," Handb. Attitudes, no. January 2005, pp. 173-222, 2005, doi: 10.1007/BF02294218.

[34] C. S. Yu, "Factors affecting individuals to adopt mobile banking: Empirical evidence from the utaut model," J. Electron. Commer. Res., vol. 13, no. 2, pp. 105-121, 2012.

[35] F. K. Y. Chan, J. Y. L. Thong, V. Venkatesh, S. A. Brown, P. J. H. Hu, and K. Y. Tam, "Modeling citizen satisfaction with mandatory adoption of an E-Government technology," J. Assoc. Inf. Syst., vol. 11, no. 10, pp. 519-549, 2010, doi: 10.17705/1jais.00239.

[36] E. Abu-Shanab, "Antecedents of trust in e-government services: An empirical test in Jordan," Transform. Gov. People, Process Policy, vol. 8, no. 4, pp. 480-499, 2014, doi: 10.1108/TG-08-2013-0027.

[37] L. Carter and F. Bélanger, "The utilization of e-government services: Citizen trust, innovation and acceptance factors," Inf. Syst. J., vol. 15, no. 1, pp. 5-25, 2005, doi: 10.1111/j.1365-2575.2005.00183.x.

[38] S. Haryono, Metode SEM untuk Penelitian Manajemen AMOS Lisrel PLS. Jakarta: Luxima Metro Media, 2017. 